\title{
PENGARUH TERAPI RELAKSASI DZIKIR TERHADAP PENURUNAN TEKANAN DARAH PADA PENDERITA HIPERTENSI
}

\author{
Lela Aini ${ }^{1}$, Lenny Astuti ${ }^{2}$ \\ Program Studi Ilmu Keperawatan STIK Siti Khadijah Palembang \\ Lela.aini15@gmail.com,Lennyastuti149@gmail.com
}

\begin{abstract}
ABSTRAK
Latar Belakang : Hipertensi merupakan salah satu pemicu terjadinya stres. Dimana reaksi di dalam tubuh dapat meningkatkan hormon epineprin dan nonepineprin yang mengakibatkan peningkatan tekanan darah, yang selanjutnya akan berdampak terhadap penurunan kualitas hidup seseorang. Penatalaksanaan hipertensi ada 2 cara yaitu pengobatan farmakologi dan terapi non farmakologi salah satunya dengan terapi Dzikir. Tujuan : untuk mengetahui Pengaruh Terapi Relaksasi Dzikir terhadap Penurunan Tekanan Darah pada Penderita Hipertensi di Poli Klinik Penyakit Dalam Rumah Sakit Bhayangkara Palembang Tahun 2018. Metode : Penelitian ini menggunakan pendekatan kuantitatif, jenis penelitian quasi eksperimen dengan desain one group pretest postest. Sampel yang digunakan adalah Pasien hipertensi di Poli Klinik Penyakit Dalam. Hasil : Berdasarkan hasil penelitian didapatkan rata-rata tekanan sistolik sebelum di beri terapi relaksasi dzikir adalah 149.52 dengan standar deviasi 8.646, dan rata-rata tekanan diastolik sebelum di beri terapi relaksasi dzikir adalah 94.76 dengan standar deviasi 5.118, sedangkan rata-rata tekanan sistolik setelah di beri terapi relaksasi dzikir adalah 136.67 dengan standar deviasi 7.303, dan rata-rata tekanan diastolik setelah di beri terapi relaksasi adalah 90.00 dengan standar deviasi 6.325. Dari hasil uji chi-square didapatkan $\rho$ value sistolik $=0,001$, dan $\rho$ value diastolik $=0,004$ dengan nilai $\alpha=0,05(p<0,05)$, hal ini menunjukan bahwa ada perbedaan yang signifikan antara tingkat konsentrasi sebelum dan setelah diberikan terapi relaksasi dzikir. Saran : Diharapkan petugas kesehatan dapat mencoba melakukan penatalaksanaan non farmakologi seperti terapi relaksasi dzikir untuk menurunkan tekanan darah pada pasien hipertensi.
\end{abstract}

Kata Kunci : Terapi Relaksasi Dzikir, Hipertensi.

\begin{abstract}
Background: Hypertension is one of the triggers for stress. Where reactions in the body can increase the hormones epineprin and nonepineprin which result in an increase in blood pressure, which in turn will have an impact on decreasing the quality of life of a person. Hypertension is a disease that can affect anyone, both young and old. Hypertension or high blood pressure is a condition when a person experiences a rise in blood pressure either slowly or suddenly (acute). As lifestyle changes follow the era of globalization, cases of hypertension continue to increase. Management of hypertension is 2 ways, namely pharmacological treatment and non-pharmacological therapy, one of them is Dzikir therapy. Objective : the effect of Remembrance Relaxation Therapy on Reducing Blood Pressure in Hypertension Patients in the Internal Medicine Clinic of Bhayangkara Palembang Hospital in 2018. Method: This study uses a quantitative approach, a type of quasi-experimental research with the design of the one group pretest posttest. The sample used is hypertensive patients at the Internal Medicine Clinic. Result: Based on the result of the study that the average systolic pressure before dzikir relaxation therapy was 149.52 with a standard deviation of 8,646, and the average diastolic pressure before treatment with dzikir relaxation was 94.76 with a standard deviation of 5,118, while the average systolic pressure after being treated dzikir relaxation is 136.67 with a standard deviation of 7,303, and the average diastolic pressure after relaxation therapy is
\end{abstract}


90.00 with a standard deviation of 6,325 . From the chi-square test results obtained $\rho$ systolic value $=0.001$, and $\rho$ diastolic value $=0.004$ with a value of $\alpha=0.05(p<0.05)$, this shows that there is a significant difference between the concentration level before and after therapy Dzikir relaxation. Suggestion : It is expected that health workers of can start to try non pharmacological treatments such as Dzikir relaxation therapy to reduce blood pressure in hypertensive patients.

\section{Keywords: Dzikir Relaxation Therapy, Hypertension.}

\section{PENDAHULUAN}

Hipertensi merupakan peningkatan tekanan darah sistolik lebih dari 140 $\mathrm{mmHg}$ dan tekanan darah diastolik lebih dari $90 \mathrm{mmHg}$ pada dua kali pengukuran dengan selang waktu lima menit dalam keadaan istirahat atau tenang. Hipertensi dapat mengakibatkan komplikasi seperti stroke, kelemahan jantung, penyakit jantung koroner (PJK), gangguan ginjal dan lain-lain yang berakibat pada kelemahan fungsi dari organ vitalseperti otak, ginjal dan jantung yang dapat berakibat kecacatan bahkan kematian. (Kemenkes RI, 2013)

Prevalensi hipertensi di dunia tahun 2015 pada penduduk umur diatas 18 tahun mencapai 1 miliar orang, Prevalensi hipertensi tertinggi di Benua Afrika yaitu $46 \%$ dan prevalensi terendah yaitu $35 \%$ ditemukan di Amerika. Menurut American Heart Association (AHA), penduduk Amerika yang berusia diatas 20 tahun menderita hipertensi telah mencapai angka hingga 74,5 juta jiwa, namun hampir sekitar 90-95\% kasus tidak diketahui penyebabnya. Sebanyak 1 milyar orang didunia atau 1 dari 4 orang dewasa menderita penyakit ini.

Berdasarkan data dari Riset Kesehatan Dasar (Riskesdas) pada tahun 2013 menunjukkan bahwa penderita hipertensi yang berusia diatas 18 tahun mencapai $25,8 \%$ dari jumlah keseluruhan penduduk indonesia (Anies, 2018). Kementrian Kesehatan Republik Indonesia (Kemenkes RI, 2017) menyatakan prevalensi masyarakat
Indonesia dengan hipertensi sebesar 30,9\% (Saundari, et. al. 2018),

Data hipertensi dari Sumatera Selatan tiga tahun berturut-turut mengalami kenaikan pada tahun 2015 berjumlah 20.848 jiwa dan pada tahun 2016 berjumlah 21.499 jiwa dan pada tahun 2017 berjumlah 25.900 jiwa (Dinkes, 2017).

Menurut data dari Dinas Kesehatan Kota Palembang, penyakit hipertensi termasuk 10 penyakit terbesar dan pada urutan kedua di kota Palembang dengan penderita pada tahun 2016 berjumlah 16.940 jiwa dan mengalami peningkatan pada tahun 2017 berjumlah 17.550 jiwa (Profil Dinkes, 2017).

Berdasarkan data yang di peroleh dari medical record Terhadap Penderita Hipertensi di Poli Klinik Rumah Sakit Bhayangkara Palembang, bahwa data hipertensi di Poli Penyakit Dalam pada tahun 2016 sebanyak 3.133 jiwa, pada tahun 2017 sebanyak 7.701 jiwa, pada tahun 2018 sebanyak 9.465 jiwa. (Rs. Bhayangkara, 2018)

Hipertensi secara umun dapat disebabkan oleh beberapa faktor diantaranya adalah usia, keturunan, jenis kelamin, faktor olahraga, pola makan, minuman beralkohol, dan stress (Anies, 2018). Gaya hidup gemar makanan fast food yang kaya lemak, asin, malas berolahraga dan mudah tertekan ikut berperan dalam menambah jumlah penderita hipertensi (Pudiastuti, 2013).

Hipertensi tidak secara langsung membunuh penderitanya, akan tetapi hipertensi memicu munculnya penyakit lain 
yang mematikan. Laporan Komite Nasional pencegahan, Deteksi, dan Penanganan Hipertensi bahwa tekanan darah yang tinggi dapat meningkatkan resiko serangan jantung, gagal jantung, stroke, dan gagal ginjal. Penanganan hipertensi bertujuan untuk mencegah morbiditas dan mortalitas akibat komplikasi kardiovaskuler yang berhubungan dengan pencapaian dan pemeliharaan tekanan darah dibawah 140/90 mmHg. Dalam penatalaksanaan hipertensi ada 2 cara yaitu pengobatan farmakologi dengan obat anti hipertensi dan terapi non farmakologi dengan cara terapi relaksasi. Teknik relaksasi yang digabungkan dengan unsur keyakinan kepada agama serta kepada Tuhan dapat meningkatkan respon relaksasi lebih kuat dibandingkan hanya relaksasi saja (Patimah, 2015)

Salah satu pendekatan keyakinan spiritual dalam agama islam yaitu dengan teknik mengingat Allah atau berdzikir sehingga nikmat Nya menghasilkan ketenangan batin, dzikir memiliki efek yang menakjubkan dalam melapangkan dada dan menenangkan hati. Melalui dzikir hilanglah segala kecemasan dan kegundahan (Sapitri, dkk, 2015)

Menurut Mustofa (2008), dzikir yang dapat diamalkan oleh umat islam dengan mengucapkan kalimat: Astagfirullah yang artinya memohon ampun kepada Allah, Subhanallah (memuji Allah), Ahamdulillah (segala puji bagi Allah), Allahu Akbar (Allah maha besar) dan Laa ilaaha illallah (tidak ada sesembahan yang benar kecuali Allah).

Menurut Shaleh (2009) menyebutkan beberapa faedah-faedah atau keutamaan dzikir adalah sebagai berikut: mengusir, mengalahkan dan menghancurkan setan, menghilangkan rasa susah dan kegelisahan hati, membuat hati menjadi senang, gembira dan tenang, dapat menghapus dan menghilangkan dosa-dosa, dapat menyelamatkan seseorang dari kepayahan di hari kiamat.
Manfaat dzikir yang dilakukan umat islam dapat menenangkan, membangkitkan percaya diri, kekuatan, perasaan aman, tentram, dan memberikan perasaan bahagia. Secara otomatis otak akan berespon terhadap pengeluaran endorphine (dihasilkan oleh kelenjar pituitary) sehingga mampu menimbulkan perasaan bahagia dan nyaman (Suryani, 2013)

Penelitian terdahulu oleh Islamiyah (2014) tentang pengaruh meditasi dzikir terhadap perubahan tekanan darah pada lansia dengan hipertensi di kelurahan Romang Polong Kabupaten Gowa. Hasil penelitian didapatkan ada pengaruh meditasi dzikir terhadap perubahan tekanan darah pada lansia dengan hipertensi dengan $p$ value $=0,008$. Hal ini juga sejalan dengan penelitian Sudiarto (2006) tentang pengaruh meditasi dzikir terhadap penurunanan tekanan darah pada usia lansia dengan hipertensi di Wilayah Emanuel Klampok Banjarnegara. Hasil penelitian didapatkan ada pengaruh terapi meditasi terhadap penurunanan tekanan darah pada usia lansia dengan $p$ value $=0,001$

Berdasarkan uraian diatas, penulis tertarik untuk meneliti tentang Pengaruh Terapi Relaksasi Dzikir terhadap Penurunan Tekanan Darah pada Penderita Hipertensi di Poli Klinik Rumah Sakit Bhayangkara Palembang Tahun 2018.

\section{METODE PENELITIAN}

Penelitian ini menggunakan desain quasy eksperimental pre test and post test control group desain. Penelitian ini membandingkan efektiftias terapi meditasi dengan terapi dzikir terhadap penurunan tekanan darah pada pasien hipertensi. Desain penelitian yang digunakan yaitu quasy eksperimental dengan pendekatan one group pre-post test design, dan tidak menggunakan kelompok kontrol.Penelitian ini memberikan intervensi kepada responden yang dilakukan tindakan perlakuan dan membandingkan sebelum dan setelah dilakukan intervensi (Notoatmodjo, 2012). 
Sampel yang akan digunakan dalam penelitian adalah seluruh penderita hipertensi di Poli Penyakit Dalam Rumah Sakit Bhayangkara Palembang.

Rumus pengambilan sampel dalam penelitian ini yaitu :

$$
\mathrm{n}=\frac{2 \sigma^{2}\left(\mathrm{z}_{1-\alpha / 2}+\mathrm{z}_{1-\beta}\right)^{2}}{\left(\mu_{1}-\mu_{2}\right)^{2}}
$$

$\mathrm{n}=50$

$$
\sigma=0,41
$$

$\mu_{1}=1,76$

$$
\mu_{2}=1,34
$$

$\mathrm{S}_{1}=0,687$

$\mathrm{Z} \alpha=1,64$

$\mathrm{S}_{2}=0,593$

$\mathrm{Z} \beta=1,28$

Keterangan :

$\mathrm{Z}_{\alpha}$ : deviat baku alfa

$\mathrm{Z}_{\beta}$ : deviat baku beta

$\sigma=\mathrm{Sp}^{2}:$ varians gabungan 1 dan 2

$\mathrm{n}$ : jumlah populasi pada penelitian terdahulu

$S$ : varians pada penelitian terdahulu

$\mu$ : rata-rata pada penelitian terdahulu (Sasono Mardiono, 2015)

Berdasarkan rumus diatas maka perhitungan untuk mendapatkan besar sampel yang di teliti adalah sebagai berikut :

$$
\begin{aligned}
\mathrm{Sp}^{2}= & \frac{\left(\mathrm{n}_{1}-1\right) \mathrm{S}_{1}{ }^{2}+\left(\mathrm{n}_{2}-1\right) \mathrm{S}_{2}{ }^{2}}{\left(\mathrm{n}_{1}-1\right)+\left(\mathrm{n}_{2}-1\right)} \\
& \frac{(50-1) 0,687^{2}+(50-1) 0,593^{2}}{(50-1)+(50-1)}
\end{aligned}
$$

$$
\begin{aligned}
& =\frac{40.18}{98} \\
& =\quad 0,41
\end{aligned}
$$

$$
\begin{aligned}
\mathrm{n} & =\frac{2 \sigma^{2}\left(\mathrm{z}_{1-\alpha / 2}+\mathrm{z}_{1-\beta}\right)^{2}}{\left(\mu_{1}-\mu_{2}\right)^{2}} \\
& =\frac{2 \times 0,41^{2}(1.96+1,28)^{2}}{(1,76-1,34)^{2}} \\
& =\frac{3,5}{0,18} \\
& =19,4+10 \%=20,9=21 \text { responden }
\end{aligned}
$$

\section{HASIL PENELITIAN \\ Analisa Univariat}

Analisis Univariat adlah cara analiis data dengan mendeskripsikan atau menggambarkan data yang telah berkumpul sebagaimana adanya tanpa membuat kesimpulan yang berlaku untuk umum.

\section{Rerata Tekanan Darah Sebelum Diberikan Terapi relaksasi dzikir}

Tabel 1.

Rerata Tekanan Darah Sebelum Diberikan Terapi Relaksasi Dzikir

\begin{tabular}{lcccc}
\hline \multicolumn{1}{c}{ Variabe } & Mean & SD & $\begin{array}{c}\text { Min- } \\
\text { Mak }\end{array}$ & $\begin{array}{c}\text { 95\% } \\
\text { CI }\end{array}$ \\
\hline Rerata & 149.5 & 8.64 & $160-$ & 145.59 \\
tekanan & 2 & 6 & 140 & - \\
darah & & & & 153.46 \\
sistol & & & & \\
sebelum & & & & \\
diberika & & & & \\
n terapi & & & & \\
relaksasi & & & & \\
dzikir & & & & \\
\hline Rerata & 94.76 & 5.11 & $90-$ & $92.43-$ \\
tekanan & & 8 & 100 & 97.09 \\
darah & & & & \\
diastol & & & & \\
sebelum & & & & \\
diberika & & & & \\
n terapi & & & & \\
relaksasi & & & & \\
dzikir & & & & \\
\hline
\end{tabular}

Dari tabel 1 diatas dapat dilihat bahwa rata-rata tekanan darah sebelum diberikan terapi relaksasi dzikir sebesar 149.52/94.76 dengan standar deviasi 8.646/5.118. Tekanan darah terendah adalah 140/90 dan 
tertinggi 160/100, dari hasil estimasi interval dapat disimpulkan $95 \%$ di yakini bahwa rata-rata tekanan darah sistol sebelum di berikan terapi relaksasi dzikir di antara 145.59 sampai dengan 153.46 dan rata-rata tekanan darah diastol sebelum diberikan terapi relaksasi dzikir diantara 92.43 sampai dengan 97.09.

\section{Rerata Tekanan Darah Setelah Diberikan Terapi relaksasi dzikir}

Hasil penelitian menunjukkan rerata tekanan darah setelah diberikan terapi relaksasi dzikir terlihat dalam tabel berikut ini:

Tabel 2.

Rerata Tekanan Darah Setelah Diberikan Terapi relaksasi dzikir

\begin{tabular}{lcccc}
\hline Variabel & Mean & SD & $\begin{array}{c}\text { Min- } \\
\text { Maks }\end{array}$ & $\begin{array}{c}\text { 95\% } \\
\text { CI }\end{array}$ \\
\hline Rerata & 136.67 & 7.303 & $130-$ & $133.34-$ \\
tekanan & & & 150 & 139.99 \\
darah & & & & \\
sistol & & & & \\
setelah & & & & \\
diberikan & & & & \\
terapi & & & & \\
relaksasi & & & & \\
dzikir & & & & \\
\hline Rerata & 90.00 & 6.325 & $80-$ & $87.12-$ \\
tekanan & & & 100 & 92.88 \\
darah & & & & \\
diastol & & & & \\
setelah & & & & \\
diberikan & & & & \\
terapi & & & & \\
relaksasi & & & & \\
dzikir & & & \\
\hline
\end{tabular}

Dari tabel 2 diatas dapat dilihat bahwa rata-rata tekanan darah setelah diberikan terapi relaksasi dzikir sebesar 136.67/90.00 dengan standar deviasi 7.303/6.325. Tekanan darah terendah adalah 130/80 dan tertinggi 150/100, dari hasil estimasi interval dapat disimpulkan $95 \%$ di yakni bahwa rata-rata tekanan darah sistol setelah di berikan terapi relaksasi dzikir di antara 133.34 sampai dengan 139.99 dan rata-rata tekanan darah diastol setelah diberikan terapi relaksasi dzikir diantara 87.12 sampai dengan 92.88 .

\section{Analisa Bivariat}

Analisa bivariat dilakukan untuk melihat perbedaan tekanan darah sebelum dan setelah pemberian terapi relaksasi dzikir.

Tabel 3

Perbedaan Tekanan Darah Sebelum dan Setelah di Berikan Terapi Relaksasi Dzikir

\begin{tabular}{|c|c|c|c|}
\hline Variabel & $\mathbf{N}$ & $\begin{array}{l}\text { Mean } \\
\text { (Min- } \\
\text { Maks) }\end{array}$ & $\rho$ value \\
\hline $\begin{array}{l}\text { Tekanan } \\
\text { darah }\end{array}$ & 21 & $\begin{array}{c}149.52 \\
(140-160)\end{array}$ & 0.001 \\
\hline $\begin{array}{l}\text { sistole pre- } \\
\text { post }\end{array}$ & & $\begin{array}{c}136.67 \\
(130-150)\end{array}$ & \\
\hline $\begin{array}{l}\text { Tekanan } \\
\text { darah }\end{array}$ & 21 & $\begin{array}{c}94.76 \\
(90-100)\end{array}$ & 0.004 \\
\hline $\begin{array}{l}\text { diastol pre- } \\
\text { post }\end{array}$ & & $\begin{array}{c}90 \\
(80-100)\end{array}$ & \\
\hline
\end{tabular}

Berdasarkan hasil penelitian dengan menggunakan Paired $T$ - test didapatkan bahwa rata-rata tekanan darah sistol sebelum diberikan terapi relaksasi dzikir $149.52 \mathrm{mmHg}$ dan setelah diberikan terapi relaksasi dzikir adalah $136.67 \mathrm{mmHg}$ dan rata-rata pada pengukuran tekanan darah diastol sebelum diberikan terapi relaksasi dzikir $94.76 \mathrm{mmHg}$ dan setelah dilakukan terapi relaksasi dzikir didapatkan rata-rata tekanan darah $90 \mathrm{mmHg}$. Hasil uji statistik sistolik didapatkan nilai $\rho$ value 0,001 dan uji statistik diastolik didapatkan nilai $\rho$ value 0,004 Karena $\rho<\alpha 0,05$ maka dapat disimpulkan bahwa ada perbedaan antara tekanan darah sebelum dan setelah pemberian terapi relaksasi dzikir.

\section{PEMBAHASAN}

\section{Tekanan Darah Sebelum Diberikan Terapi Relaksasi Dzikir}

Berdasasarkan hasil penelitian didapatkan rata-rata tekanan darah sebelum diberikan terapi relaksasi dzikir sebesar 149.52/94.76 dengan standar deviasi 8.646/5.118. Dari hasil estimasi interval dapat disimpulkan $95 \%$ di yakini bahwa 
rata-rata tekanan darah sistol sebelum di berikan terapi relaksasi dzikir di antara 145.59 sampai dengan 153.46 dan rata-rata tekanan darah diastol sebelum diberikan terapi relaksasi dzikir diantara 92.43 sampai dengan 97.09.

Tekanan darah pada pembuluh nadi merupakan peredaran darah sistemik didalam tubuh manusia. Tekanan darah dibedakan antara tekanan darah sistolik dan diastolik. Tekanan darah sistolik adalah tekanan darah ketika jantung memompa, adapun tekanan diastolik adalah tekanan darah ketika jantung beristirahat, semakin banyak darah yang di pompa ke dalam arteria menyebabkan arteria akan lebih menggelembung dan mengakibatkan bertambahnya tekanan darah. Meningkatnya tekanan darah juga dapat disebabkan karena gaya hidup gemar makanan fast food yang kaya lemak, asin, malas berolahraga dan mudah tertekan. (Savitri, 2017)

Hasil penelitian ini sejalan dengan penelitian yang dilakukan oleh Sudiarto, dkk (2016), tentang pengaruh terapi relaksasi meditasi terhadap penurunan tekanan darah pada lansia dengan hipertensi di wilayah binaan RS Emanuel Klampok Banjarnegara, didapatkan hasil nilai rata-rata tekanan darah sebelum di berikan terapi terapi relaksasi dzikir 147,3/90,7 mmHg.

Hasil penelitian ini juga sejalan dengan penelitian yang dilakukan Islamiyah, (2014), tentang perubahan meditasi dzikir terhadap perubahan tekanan darah pada lansia di kelurahan Romang Polong Kabupaten Gowa, didapatkan nilai rata-rata tekanan darah sebelum diberikan terapi terapi relaksasi dzikir 156/92 $\mathrm{mmHg}$.

Berdasarkan hasil penelitian serta teori yang ada dan penelitian terkait maka peneliti berpendapat bahwa hipertensi selain disebabkan karena gaya hidup juga disebabkan karena adanya perubahanperubahan secara biologis yang mungkin berperan pada terjadinya peningkatan tekanan darah adalah adanya perubahan curah jantung, tahanan perifer yang meningkat, aliran darah yang menurun.

\section{Tekanan Darah Setelah Diberikan Terapi relaksasi dzikir}

Berdasarkan hasil penelitian didapatkan rata-rata tekanan darah setelah diberikan terapi relaksasi dzikir sebesar 136.67/90.00 dengan standar deviasi 7.303/6.325, dari hasil estimasi interval dapat disimpulkan $95 \%$ di yakini bahwa rata-rata tekanan darah sistolik setelah di berikan terapi relaksasi dzikir di antara 133.34 sampai dengan 139.99 dan rata-rata tekanan darah diastol setelah diberikan terapi relaksasi dzikir diantara 87.12 sampai dengan 92.88.

Menurut Watanabe (2016), terapi relaksasi dzikir melibatkan berbagai daerah didalam tubuh (lengan dan kaki) efeknya menjadi hangat dan berat. Sensasi hangat dan berat ini disebabkan oleh peralihan aliran darah pusat tubuh ke daerah tubuh yang diinginkan. Tubuh merasakan hangat merupakan akibat dari arteri perifer yang mengalami vasodilatasi pembuluh darah yang dapat menurunkan tekanan darah.

Hasil penelitian ini sejalan dengan penelitian yang dilakukan oleh Sudiarto, dkk (2016), tentang pengaruh terapi relaksasi merditasi terhadap penurunan tekanan darah pada lansia dengan hipertensi di wilayah binaan RS Emanuel Klampok Banjarnegara, didapatkan hasil nilai rata-rata tekanan darah setelah di berikan terapi terapi relaksasi dzikir $139,6 / 90 \mathrm{mmHg}$.

Hasil penelitian ini juga sejalan dengan penelitian yang dilakukan Islamiyah, (2014), tentang perubahan meditasi dzikir terhadap perubahan tekanan darah pada lansia di kelurahan Romang Polong Kabupaten Gowa, didapatkan nilai rata-rata tekanan darah sebelum diberikan terapi terapi relaksasi dzikir 155/91 $\mathrm{mmHg}$.

Berdasarkan hasil penelitian serta teori yang ada dan penelitian terkait maka peneliti berpendapat bahwa penyakit hipertensi jika tidak segera ditangani maka dalam jangka panjang dapat menimbulkan 
kerusakan arteri di dalam tubuh sampai organ-organ yang mendapatkan suplai darah seperti jantung, otak dan ginjal. Hipertensi merupakan penyebab utama penyakit stroke, serangan jantung, gagal jantung, gagal ginjal, oleh karena itu sangat penting dilakukan penatalaksanaan hipertensi salah satunya tarapi non farmakologis yaitu dengan menggunakan terapi terapi relaksasi dzikir yang dapat menurunkan hipertensi.

\section{Perbedaan Tekanan Darah Sebelum dan Setelah di Berikan Terapi relaksasi dzikir}

Berdasarkan hasil penelitian dengan menggunakan Paired $T$ - test didapatkan nilai $\rho$ value sistolik $=0.001$ dan $\rho$ value diastolik $=0.004$ dengan nilai $\alpha 0,05$ karena $\rho<\alpha \quad 0,05$ maka dapat disimpulkan ada perbedaan antara tekanan darah sebelum dan setelah pemberian terapi relaksasi dzikir, maka dapat disimpulkan bahwa ada pengaruh pemberian terapi relaksasi dzikir terhadap penurunan tekanan darah pada penderita hipertensi.

Sejalan dengan teori yang di kemukakan oleh Haruyama (2014), yang menyatakan bahwa terapi relaksasi dzikir membantu tubuh untuk membawa perintah melalui auto sugesti untuk rileks sehingga dapat mengendalikan tekanan darah. Sensasi tenang, hangat yang menyebar ke seluruh tubuh merupakan efek yang bisa dirasakan dari terapi relaksasi dzikir, perubahanperubahan yang terjadi selama maupun setelah relaksasi mempengaruhi saraf otonom.

Hasil penelitian ini sejalan dengan penelitian Weddy, dkk (2016), tentang pengaruh pemberian terapi meditasi pada lansia yang mengalami hipertensi didapatkan nilai $\rho$ value sistolik $=0.000$ dan $\rho$ value diastolic $=0.001(\alpha \leq 0.05)$, sehingga ada pengaruh pemberian terapi meditasi Dzikir pada lansia yang mengalami hipetensi .

Berdasarkan hasil penelitian serta teori yang ada dan penelitian terkait maka peneliti berpendapat bahwa dalam terapi relaksasi dzikir hal yang menjadi anjuran pokok adalah penyerahan pada diri sendiri sehingga memungkinkan berbagai daerah di dalam tubuh (tangan dan kaki) menjadi hangat dan berat. Sensasi hangat dan berat ini disebabkan oleh peralihan aliran darah (dari pusat tubuh ke daerah tubuh yang diinginkan), yang menyejukkan dan merelaksasikan otot-otot di sekitarnya. Terapi relaksasi dzikir akan membantu tubuh untuk membawa perintah melalui autosugesti untuk rileks sehingga dapat mengendalikan tekanan darah dan menurunkan tekanan darah. Tubuh merasakan hangat, merupakan akibat dari arteri perifer yang mengalami vasodilatasi, sedangkan ketegangan otot tubuh yang menurun mengakibatkan munculya sensasi ringan. Perubahan-perubahan yang terjadi selama maupun setelah relaksasi mempengaruhi kerja saraf otonom. Stimulus positif dari terapi relaksasi dzikir akan menurunkan aktivitas produksi HPA (Hipotalemik Pituitary Adrenal) Axis, yang ditandai adanya penurunan hormon CRF (Corticotropin Releasing Factor) di hipotalamus dan juga akan merangsang pituitary anterior untuk memproduksi ACTH menjadi menurun. Penurunan ini akan merangsang medulla adrenal untuk memproduksi hormon katekolamin dan kartisol sebagai hormon stres menjadi menurun. Penurunan ini akan menurunkan kerja syaraf simpatis, dan sebaliknya kerja syaraf parasimpatis menjadi meningkat atau dominan sehingga menyebabkan pelebaran atau vasodilatasi pembuluh darah yang akhirnya dapat menurunkan tekanan darah. Teknik relaksasi yang dilakukan secara rutin dapat membuat peredaran darah menjadi lancar, membuat efek tenang sehingga membuat tekanan darah menjadi stabil. Sehingga dapat disimpulkan bahwa terdapat perbedaan rerata tekanan darah sebelum diberikan terapi relaksasi dzikir dan setelah diberikan terapi relaksasi dzikir.

\section{KESIMPULAN DAN SARAN}

Kesimpulan 
1. Rerata tekanan darah sebelum diberikan terapi relaksasi dzikir sebesar 149.52/94.76 $\mathrm{mmHg}$ dengan standar deviasi 8.646/5.118.

2. Rerata tekanan darah setelah diberikan terapi relaksasi dzikir sebesar 136.67/90 $\mathrm{mmHg}$ dengan standar deviasi 7.303/6.325.

3. Ada perbedaan tekanan darah sebelum dan setelah diberikan terapi relaksassi dzikir di Poli Penyakit Dalam Rumah Sakit Bhayangkara Palembang ( $\rho$ value sistolik $=0.001$ dan $\rho$ value diastolik $=0.004)$

\section{Saran}

Diharapkan bagi petugas Rumah Sakit untuk memberikan penyuluhan tentang cara mencegah terjadinya hipertensi, bagaimana gaya hidup yang sehat dan sebagainya, mulai untuk mencoba pengobatan non-farmakologi seperti terapi relaksasi dzikir.

\section{DAFTAR PUSTAKA}

Al- Qur'an. 2014. Deparemen Agama RI Al-Qur'an Terjemaah dan Tajwid. Jawa Barat : Sygma

Dinkes Sumsel. 2017. Data Hipertensi Sumatera Selatan. Sumatera Selatan

Dinkes Kota Palembang.2017. Data Hipertensi Kota Palembang

Islamiyah. Pengaruh meditasi dzikir terhadap perubahan tekanan darah pada lansia dengan hipertensi. Gowa : UIN Alauddin Makassar

Martin, Weddy \& Ponia, Mardian. 2016. Pengaruh Terapi Meditasi Terhadap Penurunan Tekanan Darah Pada Lansia Yang Mengalami Hipertensi. Bukit Tinggi : Stikes Buana Citra
Notoatmodjo, Soekidjo. 2012. Promosi Kesehatan Dan Perilaku Kesehatan. Jakarta: Rineka Cipta

Padila.2013. Asuhan Keperawatan Penyakit Dalam . Yogyakarta : Nuha Medika

Patimah, I. Suryani \& Nuraeni, A. 2015. Pengaruh relaksasi dzikir terhadap tingkat kecemasan pasien gagal ginjal kronik yang menjalani hemodialisa

Pudiastuti, Dewi Ratna.2013. Penyakit Penyakit Mematikan. Yogjakarta : Nuha Medika

RS Byangkara. Data Kunjungan Hipertensi. Palembang

Sapitri,Wahyu, dkk. 2015.Pengaruh Pemberian Terapi Dzikir Terhadap Penurunanan Tingkat Kecemasan Pasien Pre Operasi. Priwingsewu

Sudiarto. 2007. Pengaruh Terapi Relaksasi Meditasi Terhadap Penurunan Tekanan Darah Pada Lansia Dengan Hipertensi Di Wilayah Binaan Rumah Sakit Emanuel Klampok Banjarnegara, Purwokerto : Skripsi : Universitas Jendral Soedirman

Sundari, Siti. 2018. Menuju masyarakat sehat yang mandiri dan berkeadilan. Jakarta : Kemenkes

Suryani. 2015. Pengaruh Relaksasi Dzikir terhadap Tingkat Kecemasan. Bandung : Universitas Padjajaran 